\title{
Epicurean Phantasia
}

\author{
DAVID KONSTAN \\ New York University \\ dk87@nyu.edu
}

Recibido: 25/09/2019 - Aceptado: 23/09/2020

DOI https://doi.org/10.20318/fons.2020.5049

\begin{abstract}
In this paper, I examine the role of phantasia in the Epicurean theory of perception and thought. Making use of newly edited fragments of Epicurus' Peri phuseôs, and recent interpretations of the role of phantasia in Aristotle, along with received texts of Epicurus and Lucretius, I consider such vexed questions as how eidôla or simulacra are reduced in size so as to enter the eye, and the channels by which they are transmitted from the eye to the mind. I discuss further the nature of phantastikê epibolê, that is, "the projection of phantasia", and its function in processes of thinking and remembering.
\end{abstract}

Keywords. eidôla, error, phantasia, phantastikê epibolê, prolepsis, tupos

\section{Resumen}

En este artículo, examino el papel de la phantasia en la teoría epicúrea de la percepción y el pensamiento. Aprovechando de los fragmentos, recién editados, de la Peri phuseôs de Epicuro, y de nuevas interpretaciones de la función de phantasia según Aristóteles, además de textos transmitidos de Epicuro y de Lucrecio, considero problemas altamente discutidos tales como la manera en que los eidôla o simulacra se reducen de tamaño para que puedan entrar en el ojo, y los canales por los cuales se transmiten desde el ojo a la mente. Trato también de la naturaleza de la phantastikê epibolê, es decir, "la proyección de la phantasia", y su función en las actividades de pensar y recordar.

Palabras clave: eidôla, error, phantasia, phantastikê epibolê, prolepsis, tupos

In this paper, I take up the vexed question of the nature of phantasia in Epicureanism, and more particularly what Epicurus dubs phantastikê epibolê, that is, "the projection of phantasia". The core text is Epicurus' Letter to Herodotus (Ep. [2]), 49-52, which is examined in detail below. I begin, however, with a discussion of

\footnotetext{
${ }^{1}$ An earlier and much different version of this paper was delivered at a Journée d'Études on "La Connaissance de Causes", on 8 June 2017, sponsored by the GDRI AITIA/AITIAI and Le Centre Léon Robin. That version was composed during the period of my fellowship at the Paris Institute for Advanced Studies (France), with the financial support of the French State managed by the Agence Nationale de la Recherche, programme "Investissements d'avenir" (ANR-11-LABX-0027-01 Labex RFIEA+), during the period 1 February to 30 June 2017; I am pleased to acknowledge my deep gratitude for that opportunity. I am indebted to Enrico Piergiacomi for astute comments on an earlier draft of this paper, and to the reports by two anonymous readers.
}

ПНГН/FONS 5(2020), 1-18

ISSN 2445-2297 www.uc3m.es/pege
D. Konstan, Epicurean Phantasia DOI https://doi.org/10.20318/fons.2020.5049 
the Epicurean theory of sense perception, since perception is closely related to the mechanisms involving phantasia. In interpreting Epicurus' conception of phantasia, moreover, I make reference both to Democritus and to Aristotle, whose views, I believe, lie behind and stand to illuminate Epicurus' treatment. Of course, in contrast to Aristotle, Epicurus' account will have been strictly materialist, and any interpretation of his conception of phantasia must be compatible with the Epicurean physics of atomic motion in a void.

\section{Perception}

Explaining mental processes poses a special challenge to materialist theories of nature, and all the more so for one with the limited resources of ancient atomism. Perception is hard enough. Since the Epicureans appear to have rejected, or at least not exploited, geometrical optics, which assumed the transmission of visual phenomena by way of rays (cf. aktines, Epicur. Ep. [2], 49), they were left to work out the mechanics of vision and other senses solely through interactions among the atoms themselves. They postulated that objects continually emit atoms in more or less coherent formations, which in the case of sight, hearing, and smell are transmitted through the atmosphere and picked up by the sensory organ suited to receive that particular form of emission ( $E p$. [2], 48-53). These emanations must be very fine, so that they do not materially reduce the size of the original object even though they are continually being ejected (there is some evidence as well that a constant influx of

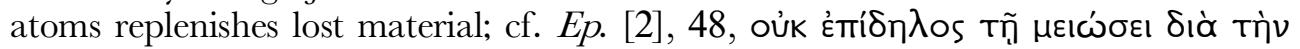
$\left.\alpha \dot{v} \tau \propto v \propto \pi \lambda n^{\prime} \rho \omega \sigma \mathrm{v}\right)$, and they must contain all the information needed to account for what we actually perceive, for example, in the case of vision, shape, size, color, and depth. The simplest account of how the effluences that enable vision convey the shape of an object is that they conform to its surface; thus the laminas, that is, eidôla or simulacra, were imagined as very thin films, curved in accord with the form of the object, that travel rapidly and in closely packed sequence from the object to the eye of the beholder.

This account gave rise to a well-known puzzle: if the simulacra indeed accurately reproduce both the shape and size of the emitting entity, how is it that images of something as large as a person or a mountain can enter the tiny aperture that is the pupil of the eye? There are various possible solutions. For example, the simulacra might shrink as they travel; alternatively, the eye might admit parts of the incoming films and then reassemble or process them, as Alexander of Aphrodisias suggested ( $O n$ Aristotle on Sense Perception 58, 3-12; 60, 3-7; Mantissa 135, 6-18)2. It now seems clear that the simulacra are in fact capable of being compressed, thanks to the splendid new edition of the second book of Epicurus' Peri phuseôs by Giuliana Leone'. We learn here, as Francesca Guadalupe Masi has recently argued in detail, that Epicurus

\footnotetext{
2 See Avotins (1980); BARNES (1989); RUdOLPH (2011), 67-83.

${ }^{3}$ LEONE (2012).
} 
outlined the means by which images, once inside the eye, are communicated along internal pores or passageways to the sensorium, located in the chest. There is a process that Epicurus calls sunizêsis, "compression" or "contraction", to which simulacra are subject; it serves to reduce their size without compromising the information concerning the original shape of the object from which they emerged, and it seems to be initiated when the simulacra encounter a substance insufficiently porous to pass through it without major alteration. This mechanism operates in tandem with a binding force or allêloukhia, which keeps the effluences together despite the collisions they undergo while passing through the air. This latter notion we know only from Book 2 of the Peri phuseôs or On Nature, and it suggests how much we may be missing when we depend exclusively on summaries, whether by Epicurus himself or in the doxographical tradition, for his doctrines. As Francesca Masi observes, «These

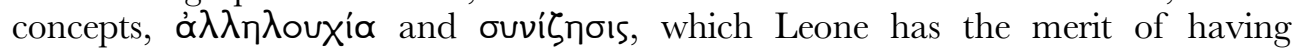
recovered, clarified, and submitted vigorously to the attention of critics, constitute the most relevant contribution of the second book of the work, On Nature, to our knowledge of the Epicurean doctrine of $\varepsilon \varepsilon^{\prime} \delta \omega \lambda \alpha »^{4}$. These same processes can, I think, be invoked to explain as well how the idols emitted by an object can diminish in size sufficiently to enter the eye, at a stage prior to the subsequent contraction that allows the impressions created within the eye to circulate through the tiny pores by which they reach the mind.

If this explanation is valid, then we may infer that Epicurus maintained that perception is a two-stage process, except in the case of those effluences that impinge directly on the mind or animus (e.g., the simulacra of the gods, who are perceived non sensu sed mente, Cic. NDI 19,49). That is, the simulacra undergo a double transformation, as they are shrunk upon entering the sense organ (the paradigm case being vision) and again when they are transmitted through still smaller pores or vessels to the mind. At the site of the sensory organs themselves, the simulacra presumably stimulate or interact with what Lucretius calls the anima, consisting of fine soul atoms that are distributed throughout the body; this is the direct locus of sensation. As Francesco Verde observes, «sensation is the result of the convergence and coexistence of the soul and the body; on the one hand, the soul contains the greatest cause of sensation; on the other hand, if it were not for the 'participation' of the body, the organism would not be able to perceive anything. Thus, it is only the close conjunction

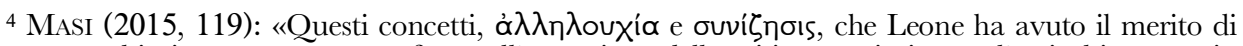
recuperare, chiarire e proporre con forza all'attenzione della critica, costituiscono l'arricchimento più rilevante apportato dal secondo libro dell'opera Sulla natura alla nostra conoscenza della dottrina epicurea degli $\varepsilon i \delta \omega \lambda \alpha »$. Masi notes that «Epicurus makes explicit reference to something that penetrates the mental aggregate as well, similar in shape to that which penetrates the sense organs. The term tà aiöntŕpı is also used by Epicurus in the Letter to Herodotus very particularly to indicate the eyes. We know, then, that the mind is in a condition to receive the same kind of stimuli as those that penetrate the eyes» (114, citing Epicur. Ep. [2], 50, 5).
} 
of the soul and the body that allows sensation» ${ }^{5}$; I add only that this juxtaposition must involve in the first instance those soul atoms that intermingle with the corporeal corpuscles at the site of perception. In the next operation, the simulacra are transmitted to the part of the soul that is concentrated in the chest, which Lucretius refers to indifferently as the animus or the mens (he employs the compound expression mens animusque, III 139)6.

There remain some questions about the process of perception, above all the role of the so-called tupoi or "impressions". Repeated impacts of streams of simulacra entering the sense organs convey an impression or tupos of an object or kind of object. Pierre-Marie Morel summarizes the process as follows: «vision results from the reception of replicas (тú $\pi \circ$ ) or images (simulacra; $\varepsilon 1 \delta \omega \lambda \alpha$ ) that are naturally emitted by the object that is seen. Since they are directly transmitted by effluences which, in ideal conditions, preserve the structure and properties of the aggregate from which they come, these replicas allow us to form a representation or impression (фаvт $\alpha \sigma i \alpha$ )

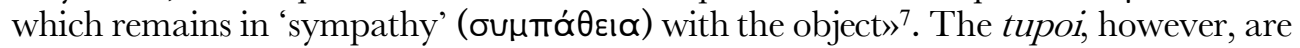
effects of the simulacra and not reducible to them. According to Democritus, at all

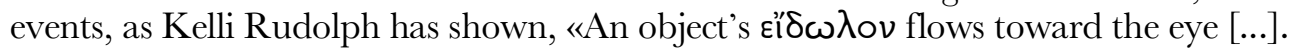
The air through which it moves [...] is condensed, i.e. ready for imprinting [...]. Eye effluences (i.e. visual rays) supply a simultaneous compression. The action of these two effluences moulds the air and results in an impression», which for Democritus takes place in the air. This impression contracts as it approaches the eye, where it is

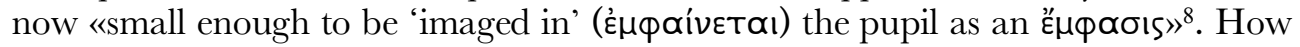
long the air imprints endured, according to Democritus, is unclear; if they persist, then, as Theophrastus (De sensu 53) objected, one ought to be able to see them even when the object itself is not present. Although Rudolph deems it «more likely [...] that air imprints dissipate», she observes that «it may be in response to challenges of this sort that the Epicureans abandoned the theory of air imprints» (p. 81). But if this is the case, where did the tupoi form? The most reasonable hypothesis, it seems to me, is that they form at or in the sensory organ, prior to the transmission by way of internal

\footnotetext{
${ }^{5} \operatorname{VERDE}(2015 \mathrm{~b}, 54)$ : «la sensazione è il risultato della convergenza e della coesistenza dell'anima e del corpo; per un verso, l'anima possiede la causa maggiore della sensazione; per un altro, se non vi fosse la 'partecipazione' del corpo, l'organismo non potrebbe percepire alcunché. Ė, dunque, solo la stretta congiunzione dell'anima e del corpo che permette la sensazione».

6 There is some question about how and whether the distinction between animus (or mens) and anima corresponds to that which Epicurus seems to have drawn between the rational and irrational parts of the soul. Diogenes Laertius (X 66 = fr. 311 Usener) cites a scholium to the Letter to Herodotus, according to which Epicurus «says elsewhere that it [the soul] is made up of very smooth and round atoms, which differ greatly from those of fire; and one part of it is non-rational [alogon], and dispersed throughout the rest of the body; but the rational part [to logikon] is in the chest [thorrax], as is evident from fears [phobol] and from joy [khara]». One might have supposed that rationality pertains to human beings only, but Lucretius uses both animus and mens of other animals (e.g., of a horse, II 265), and indeed they have to have had a central soul that processes sensations and transmit an intention (voluntas) to the rest of the body (II 261-94).
}

${ }^{7}$ MORel (2007), 30 summarizing Epicur. Ep. [2], 50.

${ }^{8}$ RUDOLPH (2011), 76-77. 
vessels to the mens or animus. It is only in the animus, located, as I have indicated, in the chest (and perhaps synonymous with the logikon part of the soul), that the tupos takes the form of a phantasia or idea proper.

\section{Idea}

The idea of idea, however, is itself complex. As Pierre-Marie Morel observes, «Epicureanism, like any empiricist philosophy, must confront the problem of the status of 'ideas,' whether these are understood as general notions, abstract representations, or simple thoughts. Since we grasp not only individuals (this cat, this tree here or that one there), but also classes or species (cats, of which that cat is an instance, trees in general), or again abstract notions (such as values), we necessarily grasp also 'ideas,' in the very broad sense that I am employing» (MOREL 2007, 25). Morel goes on to explain that «the Epicureans have available a very rich arsenal of terms, often difficult to distinguish clearly from one another, to designate the various kinds of ideas or general notions». Among these is prolêpsis, "preconception" or "presumption", which, according to Cicero, was Epicurus' own coinage (it was later adopted by the Stoics). Prolêpsis plays a special role in Epicurean epistemology. As Diogenes Laertius explains, «Preconception [prolêpsis], they [the Epicureans] say, is as it were a perception (katalêpsis), or correct opinion (doxa orthê), or conception (ennoia), or universal 'store notion' (katholikê noêsis enapokeimenê), i.e. memory of that which has frequently become evident externally: e.g. 'such and such a kind of thing is a man'»9. We may have a prolêpsis not only of a human being but also of gods, and still more generally, of justice. Animals, presumably, do not have preconceptions of these latter two (Epicurus states that «those animals which are incapable of making binding agreements with one another not to inflict nor suffer harm are without either justice or injustice», Principal Saying 32), but I assume they do have more concrete prolêpseis, inasmuch as cows and dogs can recognize other members of their species (it is possible, however, that this ability is due to memory alone). Phantasiai, however, are not concepts of this sort but rather something more like mental images that result when the tupoi that enter the senses reach the mind, and that may also be generated in the mind itself, whether by the impingement of rarefied simulacra that directly penetrate the animus or by an internal movement stimulated in some fashion by the prolepseis that are the result of repeated sensations or by more transient deposits of sensory material.

\section{Phantasia}

In a recent paper, Andree Hahmann notes that «phantasia plays a crucial role in the Epicurean theory of perception», and he adds: «This is particularly remarkable if one takes the [...] similarities to the Aristotelian position into account, since Aristotle

${ }_{9}^{9}$ D.L. X 33, trans. LONG-Sedley; quoted by Morel (2007), 27. 
sharply differentiates phantasia from perception $»^{10}$. In fact, Epicurus too distinguishes between aisthêsis, which takes place in the first instance in the anima (to employ Lucretius' handy terminology), and phantasia, which is located in the animus or mens. Nor is Aristotle himself entirely consistent in discriminating between phantasia and perception. In the De anima, he seems to allow for two types of

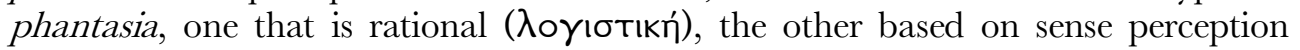
(aíOnтıкń, de An. III 11, 433b 29); non-rational animals only have the second kind $^{11}$. Despite its central importance in Aristotle's psychology, in which, as Krisanna Scheiter observes, phantasia «is necessary for dreaming, remembering, recollecting and even thinking», Aristotle's analysis in de An. III 3, his «most extensive discussion on phantasia, is extremely unclear» ${ }^{12}$.

Nevertheless, some points in Aristotle's treatment of phantasia stand out as reasonably certain. First of all, as Jessica Moss observes, «phantasia always arises from perception - that is, every episode of phantasia is based in some way on an episode of perception ${ }^{13}$. Perception leaves traces in the soul in the form of phantasmata, which derive in turn from aisthêmata (Insomn. 461a 19; cf. Mem. 451a 3-4); thus, every phantasma «is a remnant [hupoleimma] of an actual sense-impression (Insomn. 461b 21-22)» ${ }^{14}$. Aristotle further affirms that the "passages of all the sense organs $[. .$.$] run$ to the heart, or to its analogue in creatures that have no heart» ${ }^{15}$, from which it is plausible to infer that this is the pathway by which aisthêta are transmitted ${ }^{16}$. The

\footnotetext{
${ }^{10}$ HaHManN (2015), 167.
}

11 SORABJI (1993), 35, goes so far as to suggest that animals may even make certain kinds of judgments, according to Aristotle; he points specifically to the statement in de An. (II 6, 418a 21-22; III $6,430 \mathrm{~b} 29-30$ ) that a lion perceives that (öтı) an ox is nearby, and affirms that this claim implies a kind of predication. So too, in De anima Aristotle affirms that it is by virtue of phantasia that we perceive that (öTı) a white thing is round or that it is a man. Conceivably, non-rational animals, although they are deprived of reason and thus of beliefs (de An. III 3, 428a 19-24), nevertheless do possess phantasia of a quasi-rational sort and hence can make something like perceptual predications.

12 Scheiter (2012), 25. Schofield (1992), 253, wittily observes of Aristotle that «it would be a triumph of generosity over justice to pretend that he manages to combine his different approaches to phantasia with an absolutely clear head»; cited in VOGT-SPIRA (2007), 29, an article valuable for the broader connection between phantasia and literary imagination.

${ }^{13} \operatorname{Moss}(2012), 52$.

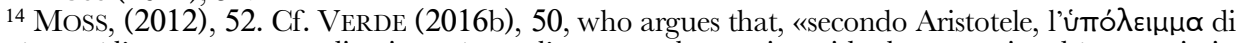
per sé non è l'oggetto esterno di cui esso è, per l'appunto, la traccia residuale: come si vedrà, proprio in

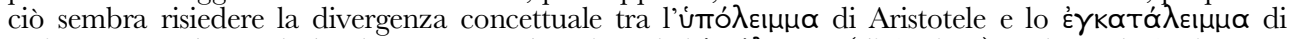
Epicuro». Verde concludes that «se secondo Aristotele l'úmó $\lambda \varepsilon ı \mu \alpha$ (di Corisco) è tale quale Corisco ma

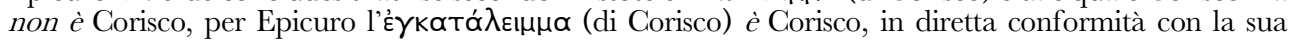
dottrina dei simulacri che fonda la veridicità/realtà della sensazione. Più chiaramente: per Aristotele il residuo/traccia è diverso dall'oggetto esterno, mentre per Epicuro esso è proprio l'oggetto» (60-61). I am not entirely convinced that Epicurus identified the residue with the object itself, but I reserve that discussion for another occasion.

${ }_{15}$ De gen. an. V 1, 781a 20-23; cited by SCHEITER (2012), 256.

16 On the physiology behind Aristotle's account of phantasmata and aisthêta, see BuBB (2019), 311: «Sensation is instantaneous, faithfully representative, and directly dependent on external objects»; phantasia, in contrast, «is directly dependent on sensation, but a step removed from external objects». At a more basic level, «sensation consists of movements imprinted on the connate pneuma, which reverberate through the pneuma that exists in both the sense organs and the blood and arrive at the 
mechanism is reminiscent of Epicurus' conception of the way in which impressions that result from the impact of simulacra are communicated to the animus, located in the chest, by way of small pores or vessels. Phantasia, however, «is independent of perceptible objects in a way that perception is not, for one can have a phantasia of something not present to perception» ${ }^{17}$; it is «a capacity for making present to the mind something one has perceived before» ${ }^{18}$. As Krisanna Scheiter observes, «perception requires the presence of a physical object, whereas phantasia does not», and so «the essential difference between perception and phantasia lies in their immediate cause» ${ }^{19}$. Something other than a perceptible object may give rise to the image represented by the term phantasia ${ }^{20}$. As Scheiter notes, "Aristotle describes phantasia as that which "produces something before the eye, just like the imagemaking (eidōlopoiountes) that occurs in memory'» (de An. III 3, 427b 18-20, cited on p. 269, Scheiter's translation). Phantasia is active, and generates an image derived from the storehouse of memory.

In her penetrating study of phantasia in Aristotle, Jessica Moss argues further that phantasia serves principally to motivate locomotion in animals: «Through bare perception we can become aware of an object, but only through phantasia can we apprehend it as something we might want to pursue or avoid» (MOSs 2012, 54). As a representation of an object of perception, it retains all the qualities of the object itself, including its affective nature as something desirable or the reverse. As she explains, "phantasia motivates by being itself pleasurable or painful, just like perception [...]. If the actual tasting of water was pleasurable, then so too will be the memory of tasting it, or the anticipation of tasting some more» (57-58; cf. Arist. $R h$. I 11, 1370a 27-35). This function of phantasia is apparently retained in Epicureanism, to judge by a crucial passage in Lucretius that is worth citing in extenso (IV 877-896)

Nunc qui fiat uti passus proferre queamus, cum volumus, quareque datum sit membra movere et quae res tantum hoc oneris protrudere nostri corporis insuerit, dicam: tu percipe dicta. dico animo nostro primum simulacra meandi accidere atque animum pulsare, ut diximus ante. inde voluntas fit; neque enim facere incipit ullam rem quisquam, [quam] mens providit quid velit ante.

common sensorium in the heart, which processes them» (292). As for phantasmata, «blood is in fact their very substrate» (295); what is more, «phantasmata are so at home in the blood because they are a part of the same digestive enterprise that blood is», though in this case it is external sense-objects rather than food that is processed (296).

17 Moss (2012), 52, citing Insomn. 459a 24-28; «even when the external object of perception (aisthèton) has departed, the impressions (aisthèmata) it has made persist, and are themselves objects of perception (aisthêta)» (460b 2-3).

${ }_{18}$ Moss (2012), 53.

19 SCHEITER (2012), 259-260.

${ }^{20}$ It is interesting that Aristotle sometimes resorts to the word eidôlon to signify "image", as at de An. III 3, 427b 20, Insomn. 462a 11-17. 
id quod providet, illius rei constat imago,

ergo animus cum sese ita commovet ut velit ire

inque gredi, ferit extemplo quae in corpore toto

per membra atque artus animai dissita vis est;

et facilest factu, quoniam coniuncta tenetur.

inde ea proporro corpus ferit, atque ita tota

paulatim moles protruditur atque movetur.

praeterea tum rarescit quoque corpus et aër,

scilicet ut debet qui semper mobilis extat,

per patefacta venit penetratque foramina largus,

et dispargitur ad partis ita quasque minutas

corporis.

895

«Next I will say how it comes about that we can carry onwards our steps when we please, how it has been given to us to move our limbs in different ways, what has caused the habit of pushing onwards this great bodily weight: do you attend to my sayings. I say that in the first place images of movement come in contact with our mind, and strike the mind, as I said before. After this comes wish; for no one ever begins anything until the intelligence has first foreseen what it wishes to do. (What it foresees, the image of that thing is present in the mind). Therefore when the mind so bestirs itself that it wishes to go and to step forwards, at once it strikes all the mass of spirit that is distributed abroad through limbs and frame in all the body. And this is easy to do, since the spirit is held in close combination with it. The spirit in its turn strikes the body, and so the whole mass is gradually pushed on and moves. Besides, at that moment the body also expands its pores, and the air (as you might expect with something always so sensitive to movement) passes and penetrates through the opened passages in abundance, and so is distributed abroad into the very smallest parts of the body» ${ }^{21}$.

Lucretius begins by affirming that, when we wish to walk, simulacra that represent the act of walking occur to the mind and impel or thrust it forward (881-882; for the sense of pulso see $O L D$ s.v., def. 8). Exactly what the source of these simulacra may be is unclear, but we must be cautious about assuming that they are external, as the Loeb translation suggests by the rendering «strike the mind» ${ }^{22}$. This is how wish (voluntas) arises, for the mind undertakes no action before it has seen what it may wish (883-884). These verses may give the impression that one must foresee an action by sheer imagination before embarking on it (so the Loeb translation). But it is important to note that providit is perfect in tense, and that provideo in this context may mean "see in advance" (OLD s.v., def. 1), in which case the sense will be that we can only wish to do something if we have previously perceived such an act, a perfectly natural assumption that accords with Aristotle's view that we only know what we have received through the senses, or in Moss's words, «every episode of phantasia is based in some way on an episode of perception». This is indeed what Lucretius affirms when he states that «an image [imago $=$ phantasia $]$ arises of what the mind sees in advance»

\footnotetext{
${ }^{21}$ Rouse-SMith (1982); but I have rendered voluntas as "wish" rather than "will," and velit as "wishes" rather than "wills".

22 Taken this way, pulsare is pleonastic, repeating the idea in accidere. The simulacra meandi may derive from stored up memories of walking, as indicated below.
} 
(885). The mind or animus then communicates its wish, conceived as an image, to the anima, which is distributed throughout the body and so strikes it in turn. Air, which, as I understand it, is somehow the vehicle for the image, passes through the opened cavities of the body and reaches to its smallest parts. The entire process looks like perception in reverse: instead of the tupos or impression produced by incoming simulacra that is transmitted by vessels from the anima to the animus, where it takes the form of a phantasia or phantasma, the imago or phantasia is passed back through the pores or cavities via the anima to the remotest limbs, which it then sets in motion. There is a strong resemblance to Aristotle's conception, translated into the medium of atomic materialism ${ }^{23}$.

\section{Phantasia and Misperception}

There is a further wrinkle in the role of phantasia, both in Aristotle's conception and in that of Epicurus, and that is its association with false perceptions. As Jessica Moss observes, "In the passages where he [i.e., Aristotle] offers definitions of

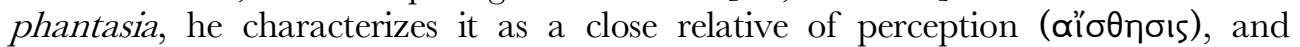
emphasizes its role in nonstandard perception and perceptual error» (MOSs 2012, 51). Thus, Aristotle writes:

«the sun appears [phainetai] a foot wide, though we are convinced that it is larger than the inhabited part of the earth. Thus either while the fact has not changed and the observer has neither forgotten nor lost conviction in the true belief which he had, that belief has disappeared, or if he retains it then his belief is at once true and false» ( $D e$ an. III 3, 428a 24-b 8, cit. SCHEITER [2012], 272).

Krisanna Scheiter explains: «In order for an object to appear to be a foot wide the perception we are having must be similar to other perceptions we have had in the past that proved to be a foot wide. When we look at the sun, the impression the sun makes on the eye sets into motion and combines with other foot-wide images that are stored in the primary sense organ» (p. 274). Thus, according to Aristotle, «our beliefs are not constrained by our current perceptual experiences. We see the sun as a foot wide, but we know that the sun is a great distance from the earth and we also know that as things move further away from us they take up less space in our visual field and therefore look smaller» (275).

It is remarkable that Aristotle here offers as an example of a mistaken phantasia a problem that will prove to be crucial for Epicurus, who defended precisely the accuracy of our perception of the sun as being a foot wide, or thereabout ${ }^{24}$. For both Epicurus and Aristotle, the sun is perceived as a small disk. Epicurus reasons that the simulacra of the sun do not shrink vastly in the course of their transmission to the eye,

\footnotetext{
${ }^{23}$ As one of the anonymous referees reminds me, Aristotle uses the word phantasia in some contexts to designate something like a faculty, whereas in Epicurus the term is restricted to the sense of mental image or the like.

${ }^{24}$ See Verde (2015b); also Verde (2016b), 46 with n. 8; cf. Romeo (1979).
} 
since fires, unlike other distant objects, are observed not to diminish much in brightness or size over distances. Thus there is no contradiction between beliefs acquired through experience and what appears to perception. If we were convinced that the sun was very remote, then we would have a false notion of its size. The cause of such an erroneous conception is not the perception itself but a belief (doxa or, in Latin, opinio) that we have added to the perception, in this case that the appearance of a fiery object like the sun diminishes in the same proportion as other objects, or that the sun is much further away than (according to Epicurus) it really is ${ }^{25}$. Conceivably, the phantasia of the sun is itself corrupted by the false opinion, and thus differs in some fashion from the aistheton, which is always valid. Alternatively, the mental image retains its integrity, and beliefs or opinions function in some other way to create a false inference concerning the sun's magnitude (the phrase "addition of opinion" would seem to distinguish the belief from the phantasia).

But what happens when the impression of something available to the senses is absent, as in the case of the image produced when we remember something that we previously saw or heard or smelled, whether in a waking state or while dreaming, or when we deliberately call something to mind? Does the difference between a phantasia and a sense impression lie, as Scheiter put it, not in the object - we see or remember the same thing - but in the source or cause?

\section{Epibolê Phantastikê}

On the usual view of Epicurean epistemology, the object of phantasia is never absent: thinking or imagining is simply another sense, attuned to a mental object, which is to say, a flow of simulacra of the finer sort that directly penetrate the animus. Take the following abbreviated account, which is, I think, broadly representative of the current communis opinio:

«As far as the ideational content of thinking - that is, the thought of something - is concerned, Epicurus proposed a radically reductive hypothesis: just as sensations occur as a result of thin films emitted by objects that enter the appropriate sense organ, so too some of these simulacra are fine enough to penetrate directly to the mind (located in the chest), and that is how we imagine such objects (e.g., gods). This process is invoked to explain not only dream images, but many kinds of mental impression, including impressions constituting voluntary thought: the latter occur when we attend to one or another of the exiguous physical films that are continuously floating through the air [...]. Imagining a thing is thus nothing more than picking out the simulacra that have been emitted by it, and which may endure beyond the life of the thing itself (hence we can imagine the dead). These mental images [...] do not differ from the information provided by the senses. Mistakes occur here too when the wrong beliefs are associated with such impressions, for example, that because we have a mental image of a dead

\footnotetext{
${ }^{25}$ For a possible reason why Epicurus insisted that the sun was both small and near the earth, see FURLEY (1996).
} 
person it follows that he or she still exists in a ghostly form. Epicurean physics proves that this is impossible» ${ }^{26}$.

I wish to take issue with this description, of which I happen to be the author. I propose that phantasiai can indeed arise in the mind by way of memory, although they are not entirely without reference to external objects. The process involved is the mysterious epibolê tês dianoias or epibolê phantastikê.

As Andree Hahmann observes, «It is well known that Epicurus ascribed to epibole a fundamental function in his epistemology. He even considered it as one of the criteria of truth (D.L. X 31, 3-5)»; actually, Diogenes Laertius says that "Epicureans" - presumably later members of the school - so classified it, but there is evidence that the doctrine in fact goes back to Epicurus himself. Hahmann notes that «there is wide disagreement about the exact nature of epibole», but, he argues, «the determination of the type of activity that is involved in perception depends on a correct interpretation of the Epicurean conception of epibole». I would say rather that epibolê is central not just to perception but also, and primarily, to ideas or phantasiai. Hahmann indeed notes that «there are two different kinds of epibole that are employed by Epicurus. He distinguishes between an epibole of the mind and an epibole of the sense organs

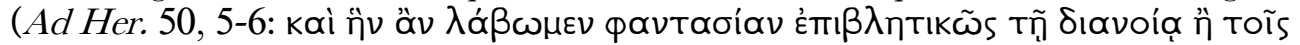

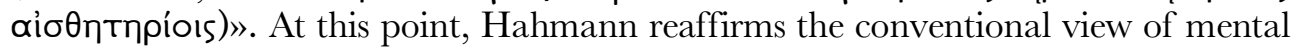
activity according to Epicurus: «With regard to their functions, it seems reasonable to assume that both are responsible for the selection of particular visual images from the vast number of images that affect the mind and the sense organs. According to a passage in Lucretius, this happens through an effort or focusing of the mind or the organs» ${ }^{27}$. There is, however, room for doubt as to whether Epicurus is distinguishing in this passage between two sorts of epibolê, one pertaining to the senses, the other to

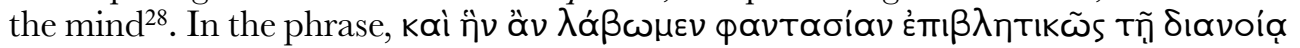

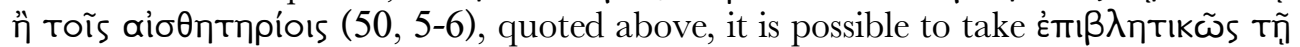

26 KONSTAN (2018).

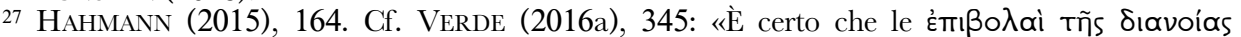
compaiono, però, più volte nell'Epistola a Erodoto $(35,36,38,50,51,69,70,83)$ e nella RS XXIV,

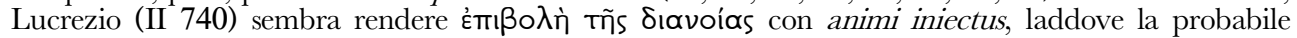
traduzione fornita da Cicerone, iniciens animus et intendens, come già nel caso delle notitiae, non è lontana da quella di Lucrezio».

${ }_{28}$ Contra VERDE (2016b), 56: «Tale pavtaoía, aggiunge Epicuro, dovrebbe essere afferrata

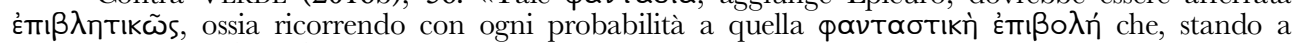
Diogene Laerzio (X 31), gli Epicurei seriori considerarono un canone epistemologico a tutti gli effetti.

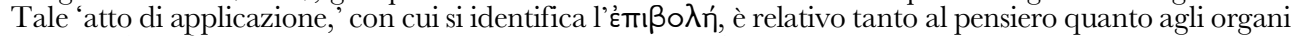

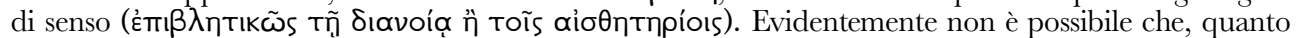

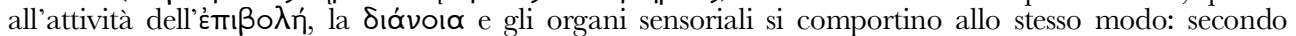

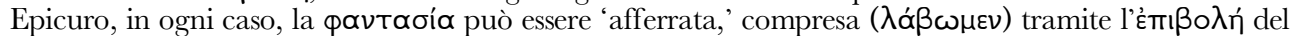
pensiero e quella dei sensi. L'esito di questo processo sarà che la qavtaóía compresa coincida

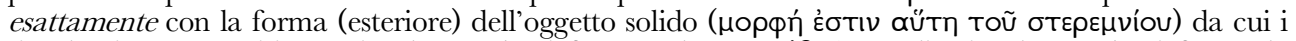

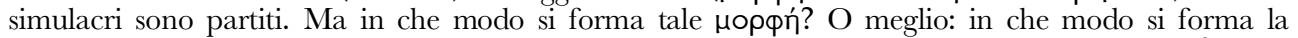

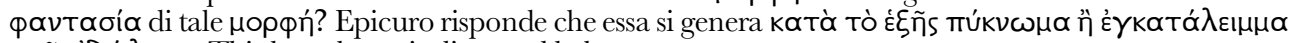
Toũ $\varepsilon i ́ \delta \omega ่ \lambda o u »$. This last phrase is discussed below. 


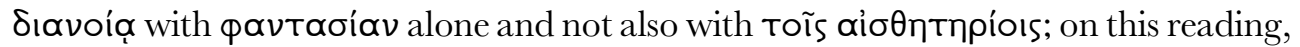
Epicurus states that we receive a phantasia either by way of an epibolê of thought or else by the aisthêtêria, without the element of projection in the latter case ${ }^{29}$. Phantasiai received via the senses would involve a two-stage process: first, simulacra will have struck the sense organ in question and transmitted to it a tupos or impression; the sensory information would then be forwarded, in compressed form but losing no relevant information, to the animus. As we have seen, Aristotle too seems to have allowed for both perceptual and mental phantasia $3^{0}$.

What is the function, then, of epibole in the reception of mental phantasiar? In accord with the prevailing view of Epicurean epistemology, epibolê has been associated with attention or focus, as a way of selecting among the innumerable simulacra floating in the ambient atmosphere. As Hahmann writes, «Today we are tempted to say that epibole draws the attention of the perceiver to certain visual images. As a result, a phantasia emerges in the soul». Hahmann immediately adds, however, that «it is problematic to connect epibole with attention taken in an unqualified sense. As some interpreters note, epibole occurs in dreams as well. Therefore, it is impossible to interpret epibole in line with just any form of deliberate conscious attention» ${ }^{31}$. But if epibolê does not represent an act of attention, what does it do? As a projection, if that is the right translation, it would appear to operate in the opposite direction to the reception of a phantasia, indicated by the term lambanô.

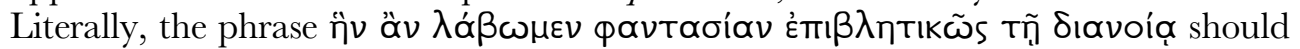
mean: "whatever phantasia we receive in the mind by projection (or by projection of the mind)". To unpack this condensed expression, it is necessary to examine the entire passage in detail; for convenience, I divide it into two sections, which I discuss in turn.

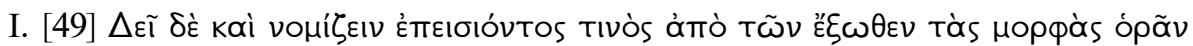

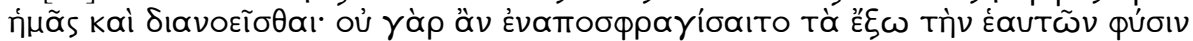

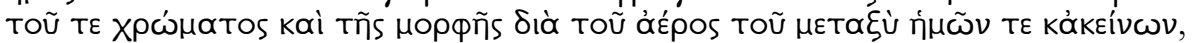

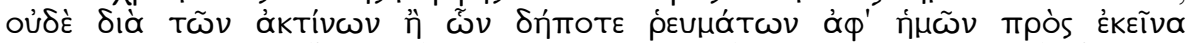

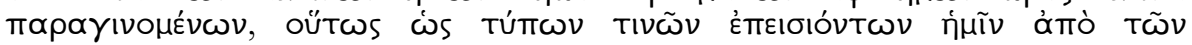

29 Aisthêteria presumably refers to the sense organs such as the eye and ear, though it may conceivably represent the seat where sensory information is processed, located in the mind.

${ }^{30}$ Runia (2018) argues that the Placita had sources other than those recorded in Diogenes Laertius;

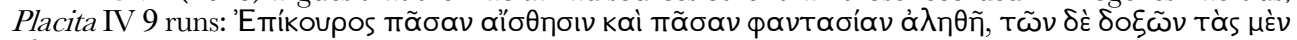

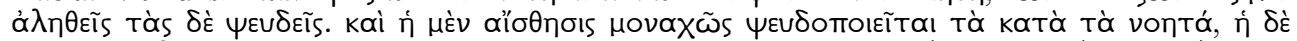

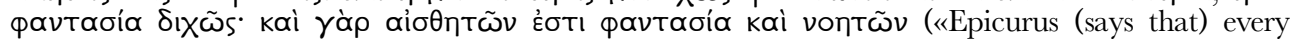
sensation and every impression is true, but of the opinions some are true and some false; and the sensation gives us a false picture in one respect only, namely with regard to objects of thought; but the impression does so in two respects, for there is impression of both sense objects and objects of thought», trans. Runia 429-430). A fragment from one of the lost books of Epicurus (fr. 38 Arrighetti) may suggest an association between phantasia and the logikon part of the soul, but the condition of the text renders any interpretation insecure:

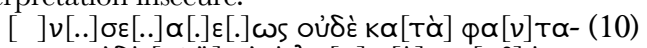

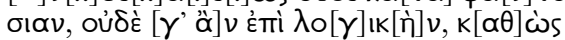

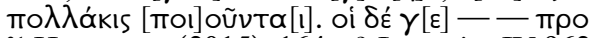

${ }^{31}$ Hahmann (2015), 164; cf. Lucretius IV 962-1029. 


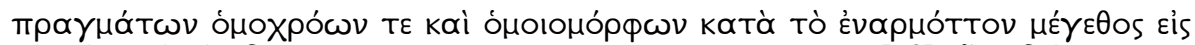

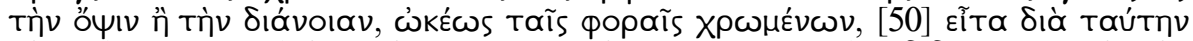

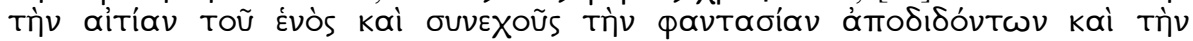

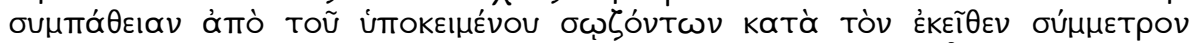

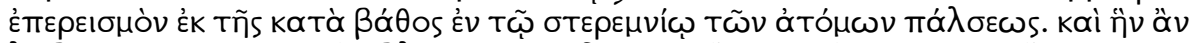

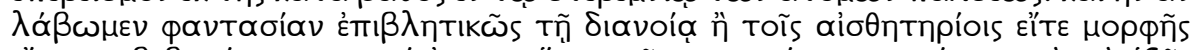

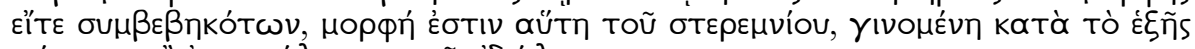

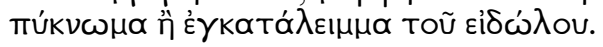

I. [49] «Now we must suppose too that it is when something enters us from external objects that we see and think of their shapes. For external objects could not stamp on

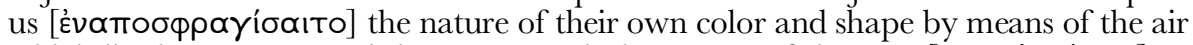

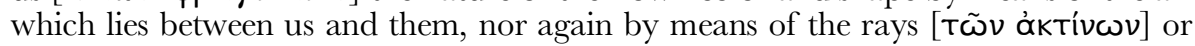
effluences of any sort which pass from us to them - nearly so well as if certain

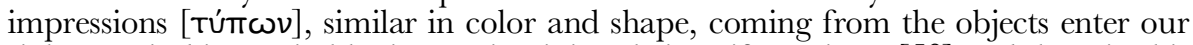
sight or mind in a suitable size, maintaining their swift motions, [50] and then, in this

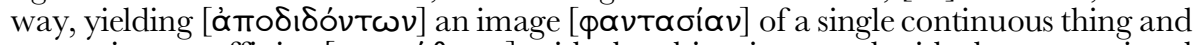

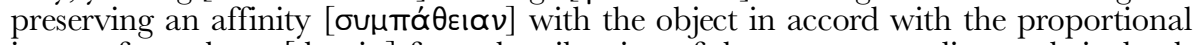
impact from there, [that is,] from the vibration of the atoms according to their depth

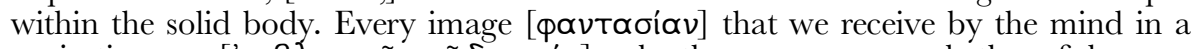

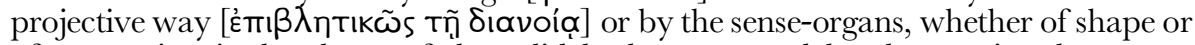
of properties, is the shape of the solid body, generated by the continual pressure

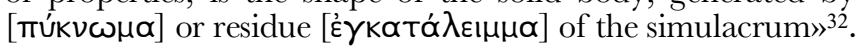

Epicurus begins by distinguishing his theory of perception from two others. First is the notion that external objects leave a seal in the air between themselves and the observer - clearly an allusion to Democritus' view of the way in which the tupos is produced at the intersection of the $\varepsilon^{\prime} \delta \omega \lambda$ ov of the object that flows toward the eye and the eye's own effluences. Second is the idea that vision results from rays that travel from the eye to the object: this is the so-called extramission account, as opposed to intromission, by which the motion is from the object to the eye - a view associated principally with Empedocles and Plato ( $T_{i} .45 \mathrm{~b}-46 \mathrm{a}$ ). Epicurus might easily have incorporated extramission in his atomic system, since simulacra are constantly emitted from the eye as well as from other objects, and if impressions or tupoi are lodged in the sensory organs, this information too might be carried by the effluences. But Epicurus does not apply the terminology of projection to tupoi but rather to phantasiai, and more specifically those received by the mind. Mental images would thus appear to involve a two-way process, both afferent (lambanein) and efferent (ekballein): we receive images mentally in a way that involves a kind of projection. But how does this work - what is projected, and to what destination? I will suggest that phantasiai in the mind are received from memory (or stored up images) and projected or emitted in turn to the sensory organ, by the same vessels along which the tupoi were originally transmitted to the animus. Before proceeding further with the demonstration, we may turn to the second half of the passage under consideration

32 My translation; text as in DoRANDi (2013), except where noted. 
(words in square brackets and smaller type are not translated; the reader is forewarned that the text is in some places highly insecure; see below):

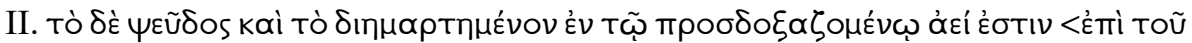

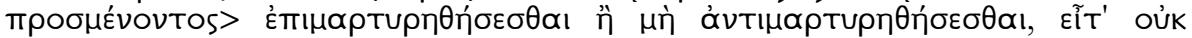

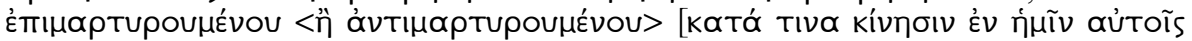

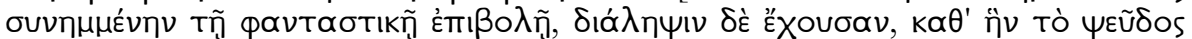

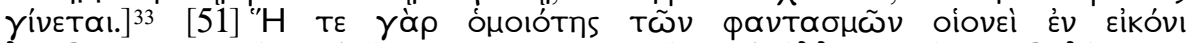

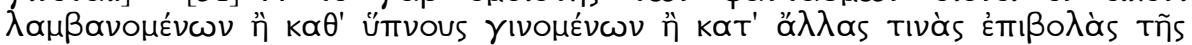

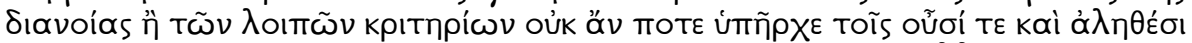

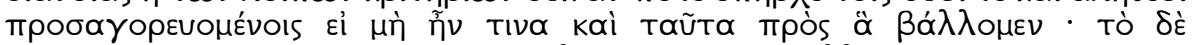

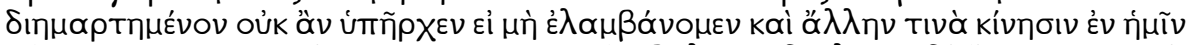

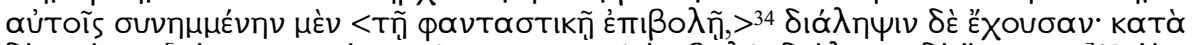

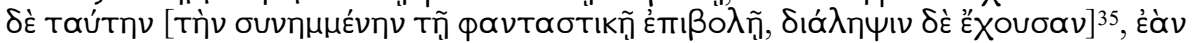

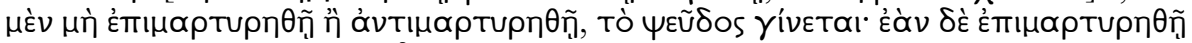

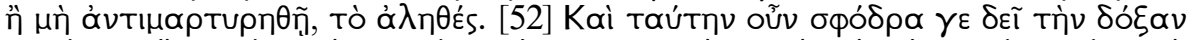

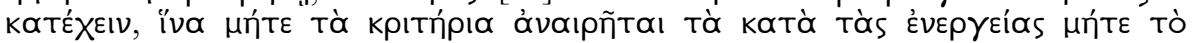

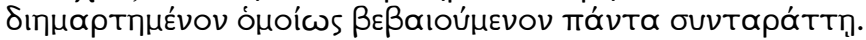

II. «Now falsehood and error always lie in the addition of opinion with regard to what is waiting to be confirmed or not disconfirmed, and then is not confirmed or is

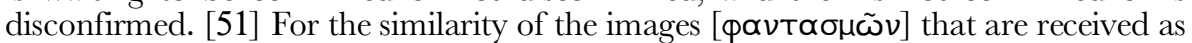

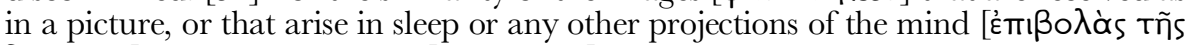

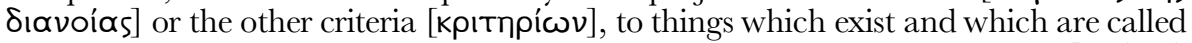
true could not be if there were not these things against which we project [ $\pi \rho$ òs ä

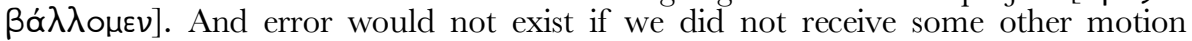
[Kívnoıv] within ourselves that is fitted ${ }^{36}$ to the imagistic projection [фаvтабтाкñ

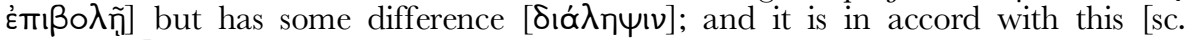
projection] ${ }^{37}$, if it is not confirmed or is disconfirmed, that falsehood arises, but if it is confirmed or not disconfirmed, the truth. [52] It is therefore necessary to hold on firmly to this belief, so that neither may the criteria in respect to actualities be destroyed nor error be equally established and confound everything».

Epicurus' discussion of imagistic projection is closely bound up with his analysis of error. Accurate images reach the mind through various channels, but they are subject to distortion because of beliefs that we hold that are not properly derived from sensory or mental inputs but arise in other ways (Epicurus does not specify here how we acquire false opinions, but they are caused partly by mistaken inferences, for example concerning the distance of the sun on the analogy with other perspectival phenomena,

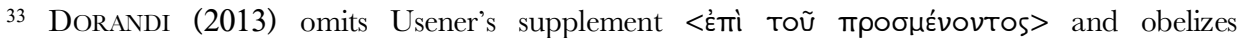

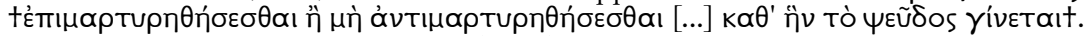

34 Supplied by Usener; DORANDI (2013) omits it.

35 The phrase is omitted in ms. Z, and marked as a gloss by Usener; it is enclosed in curly braces by Dorandi.

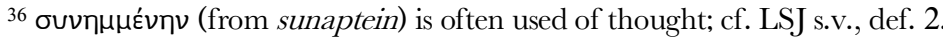

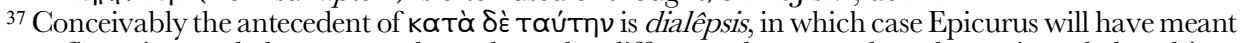
that confirmation and the reverse depend on the difference between the phantasia and the object; however, I think it more likely that the epibole is meant, as the criterion that allows one to verify the accuracy of the phantasia. 
and partly from commonplace but erroneous habits of thought, as in the case of superstitions regarding the nature of the gods). Physically, such fallacious opinions take the form of mental motions, which indeed bear a relation to the images we receive either directly by the mind or by the senses, but nevertheless differ from them in some respect. To eliminate such deviations, it is necessary to test our mental images against their external sources, to see whether they are confirmed or disconfirmed. This takes place by projecting the phantasia onto the source of the image. This might be conceived of as the incoming simulacra, but because Epicurus rejects extramission in the visual process, it is likely that the projection is entirely internal to the organism. It is when the projected phantasia encounters the tupos from which it originated that it can be confirmed, which is to say, shown to match the impression, or else disconfirmed, due to its deviation (dialêpsis) from it: there is not a perfect fit. Such projection is the process in which one must consistently engage to be sure that our ideas are true. It may thus be regarded as a criterion, according to Epicurean epistemology, since, like perception, the pathê of pain and pleasure, and the prolêpseis, it delivers the truth about the world.

Some further observations are in order. First, projection is not only a means of putting images to the test; it occurs on a regular basis as one of the ways we acquire information, along with, for example, visions we have while asleep. There seems to be a constant back and forth between the senses and the animus or dianoia, presumably along the pores or vessels by which sensory information is transmitted to the mind. Second, it must be acknowledged that the text of Epicurus' letter is rather a mess; this pertains not only to the obvious repetitions and misplaced phrases, which editors adjust in various ways, but also to the reading of crucial words. The prime instance is the phrase, "if there were not these things against which we project". The last words

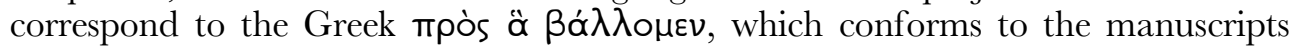
(though some read ö instead of $\ddot{\alpha}$ ) and is retained by Dorandi, but was emended by

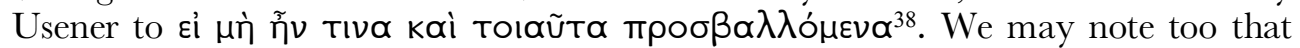
confirmation here is not deduction or inference, but takes the form of a comparison of the image in our mind with the imprint on the senses (or, it may be, directly on the mind), which involves, on an atomistic account, the physical encounter of the image with the corresponding tupos - a process that may be deliberate but, I presume, need not be: there may be an ongoing interchange along the connecting apertures of which we must simply take notice (or hold on to the belief, as Epicurus puts it). The same process is at work in non-human animals, I suppose, but since they do not have beliefs, there is no danger that their mental images will be biased and so the projected phantasiai will always correspond accurately to the sensory impression ${ }^{39}$.

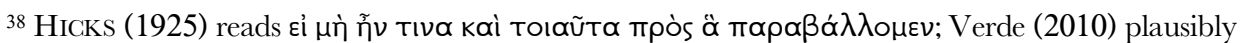

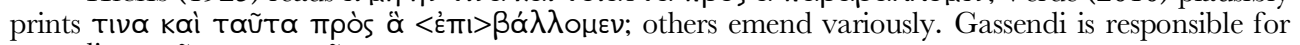
emending TaũTa to TolaũTa.

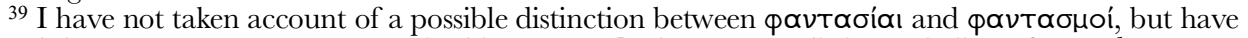
treated the two terms as synonymous in this context. Both terms are distinct, I believe, from phantasma, 


\section{Conclusion}

Since all perceptions are true, according to Epicurus, and yet people clearly have incorrect ideas about the world, it was incumbent upon the Epicureans to explain how such mistaken conceptions arise. The answer lay in atomic motions inside the mens or animus that alter and distort the phantasiai, which originate in the transmission of impressions from the senses to the mind but are subject to internal influences. These phantasiai are able to circulate back to the sensory organs by the same vessels that communicate to the animus the tupoi produced by simulacra. There, they either match the sensory impressions or differ in some respect; if they differ, it is a sign that they are erroneous. The important thing is to be attentive to possible discrepancies. The projected mental image will, upon contact, indicate whether it is true or not, and in this respect constitutes a valid criterion.

\section{References}

Avotins (1980):

Avotins, I., «Alexander of Aphrodisias on Vision in the Atomists», The Classical Quarterly XXX, 429-454.

Barnes (1989):

Barnes, J., «The Size of the Sun in Antiquity», Acta Classica Universitatis Scientiarum Debrecensis XXV, 29-41, repr. in Barnes, J., Mantissa: Essays in Ancient Philosophy, IV, Oxford 2015, 1-20.

Bubb (2019):

Bubb, C., «The Physiology of Phantasmata in Aristotle: Between Sensation and Digestion», Apeiron LVII, 273-315.

Dorandi (2013):

Dorandi, T., Diogenes Laertius: Lives of Eminent Philosophers, Cambridge.

Furley (1996):

Furley, D., «The Earth in Epicurean and Contemporary Astronomy«, in Giannantoni, G., Gigante, M. (eds.), Epicureismo greco e romano: Atti del congresso internazionale (Napoli, 19-26 maggio 1993), I, Napoli, 119-125.

which seems to mean "appearance". At D.L. X 31, фavтó ou aт a are the images perceived by madmen. At Epicur. $E_{p}$. [2], 75, they refer to the individual (' $\delta \delta^{\prime} \alpha$ ) way in which things appear to different peoples or ethnic groups, which explains the differences among languages. Cf. Pyth. 87 on the multiple

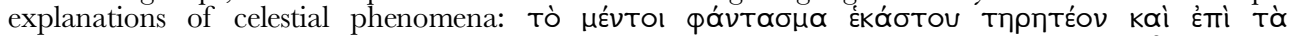

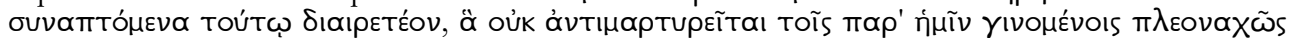

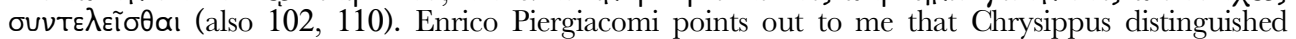
between phantasia, phantaston, phantastikon and phantasma (SVF II, 54); the first two are always true, while the latter two may be empty and false (Chrysippus gives as an example of phantasmata the visions of the Furies that Orestes wrongly believes to be real). I think it is entirely possible that Chrysippus derived this distinction from Epicurus (just as the Stoics took over the term prolêpsis and much else from the Epicureans, adapting the earlier doctrine to their own system); a full analysis must await a future discussion. 
Hahmann (2015):

Hahmann, A., «Epicurus on Truth and Phantasia», Ancient Philosophy XXXV, 155-182.

Hicks (1925):

Hicks, R.D., Diogenes Laertius: Lives of Eminent Philosophers, Cambridge MA.

Konstan (2018):

Konstan, D., «Epicurus», in Zalta, E.N. (ed.), The Stanford Encyclopedia of Philosophy (Summer 2018 Edition), URL = https://plato.stanford.edu/archives/sum2018/entries/ epicurus.

Leone (2012):

Leone, G. (ed.), Epicuro: Sulla natura. Libro II, Napoli.

Masi (2015):

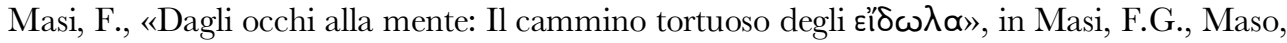
S. (eds.), Epicurus on Eidola: Peri Phuseos Book II. Update, Proposals, and Discussions, Amsterdam, 107-134.

Morel (2007):

Morel, P.-M., «Method and Evidence: On Epicurean Preconception», Proceedings of the Boston Area Colloquium in Ancient Philosophy XXIII, 25-48.

Moss (2012):

Moss, J., Aristotle on the Apparent Good: Perception: Phantasia, Thought, and Desire, Oxford.

Romeo (1979):

Romeo, C., «Demetrio Lacone sulla grandezza del sole (PHerc. 1013)», Cronache Ercolanesi IX, 11-35.

Rouse-Smith (1982):

Rouse, W.H.D. (trans.), Lucretius: On the Nature of Things, revised by Smith, M.F., Cambridge MA.

Rudolph (2011):

Rudolph, K., «Democritus' Perspectival Theory of Vision», Journal of Hellenic Studies CXXXI, 67-83.

Runia (2018):

Runia, D.T., «Epicurus and the Placita», in Mansfeld, J., Runia, D.T. (eds.), Aëtiana IV: Papers of the Melbourne Colloquium on Ancient Doxography, Leiden, 377-432.

Sorabji (1993):

Sorabji, R., Animal Minds and Human Morals: The Origins of the Western Debate, Ithaca NY.

Scheiter (2012):

Scheiter, K.M., «Images, Appearances, and Phantasia in Aristotle», Phronesis LVII, 251-278. Schofield (1992):

Schofield, M., «Aristotle and the Imagination», in Nussbaum, M.C., Rorty, A.O. (eds.), Essays on Aristotle's De anima, Oxford, 249-277.

Verde (2010):

Verde, F., Epistola ad Erodoto, Roma. 
Verde (2015a):

Verde, F., «Epicuro e la grandezza del sole: sul testo di Pyth. 91», Méthexis XXVIII, 104110.

Verde (2015b):

Verde, F., «Monismo psicologico e dottrina dell'anima in Epicuro e Lucrezio», in Canone, E. (ed.), Anima-corpo alla luce dell'etica: antichi e moderni, Firenze, 49-64.

Verde (2016a):

Verde, F., «Epicuro nella testimonianza di Cicerone: la dottrina del criterio», in Tulli, M. (ed.), Testo e forme del testo: Ricerche di filologia filosofica, Pisa, 335-368.

Verde (2016b):

Verde, F., «Percezione, errore e residuo percettivo in Aristotele, Epicuro e Alessandro di Afrodisia», Giornale Critico della Filosofia Italiana, Serie 7, XII, 44-62.

Vogt-Spira (2007):

Vogt-Spira, G., «Secundum verum fingere: Wirklichkeitsanschauung, Imagination und Fiktionalität: Epistemologische Überlegungen zur hellenistisch-römischen Literaturkonzeption», Antike und Abendland LIII, 21-38. 